NASA/TM-2007-214691
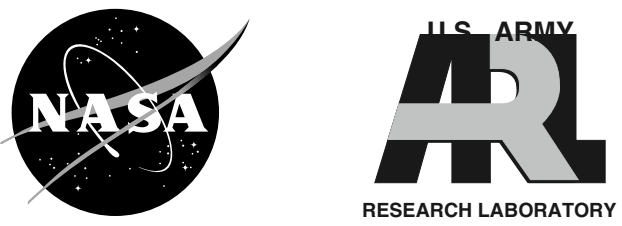

\title{
Design, Fabrication and Performance of Open Source Generation I and II Compliant Hydrodynamic Gas Foil Bearings
}

Christopher DellaCorte

Glenn Research Center, Cleveland, Ohio

Kevin C. Radil

U.S. Army Research Laboratory, Glenn Research Center, Cleveland, Ohio

Robert J. Bruckner and S. Adam Howard

Glenn Research Center, Cleveland, Ohio 


\section{NASA STI Program . . . in Profile}

Since its founding, NASA has been dedicated to the advancement of aeronautics and space science. The NASA Scientific and Technical Information (STI) program plays a key part in helping NASA maintain this important role.

The NASA STI Program operates under the auspices of the Agency Chief Information Officer. It collects, organizes, provides for archiving, and disseminates NASA's STI. The NASA STI program provides access to the NASA Aeronautics and Space Database and its public interface, the NASA Technical Reports Server, thus providing one of the largest collections of aeronautical and space science STI in the world. Results are published in both non-NASA channels and by NASA in the NASA STI Report Series, which includes the following report types:

- TECHNICAL PUBLICATION. Reports of completed research or a major significant phase of research that present the results of NASA programs and include extensive data or theoretical analysis. Includes compilations of significant scientific and technical data and information deemed to be of continuing reference value. NASA counterpart of peer-reviewed formal professional papers but has less stringent limitations on manuscript length and extent of graphic presentations.

- TECHNICAL MEMORANDUM. Scientific and technical findings that are preliminary or of specialized interest, e.g., quick release reports, working papers, and bibliographies that contain minimal annotation. Does not contain extensive analysis.

- CONTRACTOR REPORT. Scientific and technical findings by NASA-sponsored contractors and grantees.
- CONFERENCE PUBLICATION. Collected papers from scientific and technical conferences, symposia, seminars, or other meetings sponsored or cosponsored by NASA.

- SPECIAL PUBLICATION. Scientific, technical, or historical information from NASA programs, projects, and missions, often concerned with subjects having substantial public interest.

- TECHNICAL TRANSLATION. Englishlanguage translations of foreign scientific and technical material pertinent to NASA's mission.

Specialized services also include creating custom thesauri, building customized databases, organizing and publishing research results.

For more information about the NASA STI program, see the following:

- Access the NASA STI program home page at http://www.sti.nasa.gov

- E-mail your question via the Internet to help@sti.nasa.gov

- Fax your question to the NASA STI Help Desk at 301-621-0134

- Telephone the NASA STI Help Desk at 301-621-0390

- Write to: NASA Center for AeroSpace Information (CASI) 7115 Standard Drive Hanover, MD 21076-1320 
NASA/TM-2007-214691

ARL-TR-4102
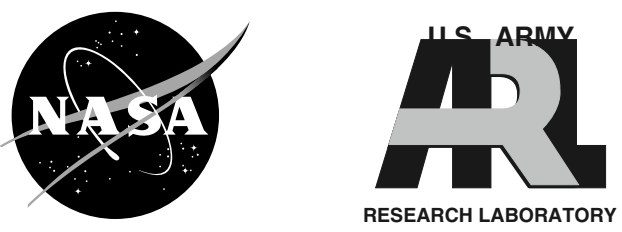

\section{Design, Fabrication and Performance of Open Source Generation I and II Compliant Hydrodynamic Gas Foil Bearings}

Christopher DellaCorte

Glenn Research Center, Cleveland, Ohio

Kevin C. Radil

U.S. Army Research Laboratory, Glenn Research Center, Cleveland, Ohio

Robert J. Bruckner and S. Adam Howard

Glenn Research Center, Cleveland, Ohio

National Aeronautics and

Space Administration

Glenn Research Center

Cleveland, Ohio 44135 


\section{Acknowledgments}

The authors would like to acknowledge the support of the Fundamental Aeronautics Program Office, Subsonic Rotary Wing Project.

Trade names and trademarks are used in this report for identification only. Their usage does not constitute an official endorsement, either expressed or implied, by the National Aeronautics and Space Administration.

Level of Review: This material has been technically reviewed by technical management.

Available from

NASA Center for Aerospace Information 7115 Standard Drive

Hanover, MD 21076-1320
National Technical Information Service 5285 Port Royal Road Springfield, VA 22161 


\title{
Design, Fabrication and Performance of Open Source Generation I and II Compliant Hydrodynamic Gas Foil Bearings
}

\author{
Christopher DellaCorte \\ National Aeronautics and Space Administration \\ Glenn Research Center \\ Cleveland, Ohio 44135 \\ Kevin C. Radil \\ U.S. Army Research Laboratory \\ Glenn Research Center \\ Cleveland, Ohio 44135 \\ Robert J. Bruckner and S. Adam Howard \\ National Aeronautics and Space Administration \\ Glenn Research Center \\ Cleveland, Ohio 44135
}

\begin{abstract}
Foil gas bearings are self-acting hydrodynamic bearings made from sheet metal foils comprised of at least two layers. The innermost "top foil" layer traps a gas pressure film that supports a load while a layer or layers underneath provide an elastic foundation. Foil bearings are used in many lightly loaded, high-speed turbo-machines such as compressors used for aircraft pressurization, and small micro-turbines. Foil gas bearings provide a means to eliminate the oil system leading to reduced weight and enhanced temperature capability. The general lack of familiarity of the foil bearing design and manufacturing process has hindered their widespread dissemination. This paper reviews the publicly available literature to demonstrate the design, fabrication and performance testing of both first and second generation bump style foil bearings. It is anticipated that this paper may serve as an effective starting point for new development activities employing foil bearing technology.
\end{abstract}

\section{Introduction}

Gas foil bearing technology was first developed in the 1960's to support high speed rotating shaft systems that could not operate using conventional oil-lubricated bearings or rigid geometry gas bearings due to contamination, speed and thermal stability requirements [1-3]. Foil bearing technology has evolved to the point where they are in commercial use in specialized applications such as air cycle machines, turboexpanders and compressors and small micro-turbine systems [4-6]. Foil bearings have been demonstrated as "proof-ofconcepts" in diesel engine turbochargers, auxiliary power units (APUs) and selected hot section bearings in gas turbines [7-9].

The widespread commercialization of foil bearings into more demanding and higher volume applications, such as automotive turbochargers, has been hindered in part by a paucity of bearing suppliers as well as a generally poor understanding of foil bearing design and manufacturing procedures. Current foil bearing expertise resides with a relatively small number of corporations and practitioners. As with many technologies that are limited to low production number applications, there is a general lack of familiarity in the manufacturing community with foil bearing technology. As such, a certain degree of mystery has developed concerning basic aspects of the technology such as bearing design, fabrication and performance. While the most modern, high performance foil bearings are protected by patents, many bearing designs with performance adequate for certain applications, and as a basis for future development, are available as open source technologies such as expired patents $[10,11]$.

Because most turbomachinery developers lack hands-on experience with the technology, there exists a perception that foil gas bearing technology carries with it too high a risk of failure to attempt implementation in new applications. The fact that multiple bearing suppliers do not generally exist for a particular application only adds to this perceived risk.

The authors have conducted extensive research over the past decade to demonstrate that foil bearings are suitable and desirable alternatives to conventional bearings for a variety of applications, particularly Oil-Free turbochargers and small gas turbines $[7,8]$. Several foil bearing performance models useful for sizing bearings and assessing feasibility of candidate rotor systems have also been developed [12,13]. Nonetheless, barriers still exist which impede the implementation of foil bearings into new systems.

The following paper combs the literature for publicly available information related to early foil gas bearing design and fabrication and describes a project to reproduce and characterize first (Generation I) and second-generation (Generation II) journal foil bearings. The bearings are designed, fabricated and tested to demonstrate the processes needed to develop bearings for new turbomachinery applications. A novel tooling 
system is described to enable, with a modest financial investment, the convenient production of a wide range of foil bearing design geometries. The performance of these Generation I and II bearings will be compared to state-of-the-art, commercially available Generation III bearings. This work will hopefully spur more rapid deployment of foil gas bearings into advanced turbomachinery systems. Further, it is expected that after the basic design and manufacturing art is better understood by system developers, there may arise more cooperative collaborations between the bearing user community and foil bearing practitioners.

\section{Background}

Foil gas bearings are self-acting, compliant surface, hydrodynamic bearings that use ambient gas as their working fluid. They were originally developed in the late 1950's as a natural outgrowth of the high-speed magnetic tape recorder industry [2]. As a result, the earliest bearing designs resembled metal tapes partially wrapped around rotating shafts. These primitive bearings exhibited very low load capacity and displayed performance characteristics dominated by the tension in the foils used to maintain their conformal geometry [1]. Later designs, upon which all currently commercialized bearings are based, employed an elastic foundation made up of continuous or discrete springs that provide support to a compliant membrane or top foil which forms and contains the resulting selfgenerated hydrodynamic gas film pressure. It is this pressure that supports the bearing load and causes elastic deformation of the bearing's spring understructure. Bearings which operate on these principles are termed "bending dominated" foil gas bearings because the foil stresses are largely due to bending rather than tension. Figure 1 shows a sketch of the earliest "tension dominated" tape type foil bearings. Figure 2 shows sketches of early, first generation, "bending dominated" foil journal bearings.

During operation, a hydrodynamic air film separates the rotating shaft from the stationary foils. At start-up and shutdown, when the shaft surface velocity is insufficient to generate adequate gas film pressure, the spring preload forces, combined with shaft deadweight loading, cause rubbing between the top foil and the shaft surfaces. This brief period of sliding contact necessitates the use of solid film lubricants on either the shaft surface, the foil surface or both, in order to prevent excessive friction and wear. For low temperature bearing applications, polymer based films such as PTFE (polytetrafluoroethylene) are effective at reducing friction and wear [14]. For high temperature applications, metal-ceramic coatings have proven successful [15].

In order to better understand foil bearing design philosophy and generalized performance characteristics, it is important to appreciate the various physical factors that govern their operation. For instance, there exists a practical range of gas film thicknesses over which all foil bearings reliably operate. This range is analogous to the operating film thickness of oillubricated sleeve bearings. In conventional bearings, using oil of typical viscosities, one encounters film thicknesses on the order of 0.025 to $0.125 \mathrm{~mm}$ (0.001 to 0.005 in). Films that are thinner due to excessively high loads, low speeds or low lubricant viscosities can lead to shear damage of the fluid or surface asperity contact, resulting in wear and possibly damage.

In gas bearings, which generally have well-polished surfaces, somewhat thinner films are typical; in the range of 0.005 to $0.025 \mathrm{~mm}(0.0002$ to $0.001 \mathrm{in})$ because of lower viscosity. This practical range of gas film thickness combined with typical shaft surface velocities (rpm), on the order of several hundreds of meters per second (hundreds of feet per second), lead to foil bearing gas film pressures on the order of hundreds of kilo-Pascal (tens of psi). Oil-lubricated bearings, using much higher viscosity lubricants, generate much higher film pressures of mega-Pascal levels (hundreds to thousands of psi). The practicable range of gas foil bearing film thicknesses and film pressures has a direct impact on the elastic support structure design and stiffness required for proper operation.

An important mechanism influencing foil bearing operation is that the hydrodynamic gas film pressure causes a commensurate elastic deflection of the foil elements [16]. Since minimum realistic or practical film thicknesses dictate local film pressures of tens to hundreds of psi, the elastic foundation must be of approximately equivalent spring stiffness. If the elastic foil structure were too stiff, the bearing behaves as a rigid gas bearing and would not be able to accommodate shaft misalignment or account for edge leakage effects. If the foil structure were appreciably softer than the gas film, the bearing would not adequately control shaft motion due to environmental loads. These factors suggest that all operating foil gas bearings possess very similar foil structures when viewed in terms of their structural stiffness characteristics.

The bearings tested in the present work exhibit static spring stiffness values of about $2 \mathrm{~N} / \mathrm{m}$ for each square millimeter $(5,000 \mathrm{lb}$ per inch for each square inch) of projected bearing area. This value was experimentally obtained through simple load - displacement measurements, sometimes referred to as "load-deflection tests", similar to those described in reference 19. This value is typical for foil gas bearings using air at atmospheric pressure as their working fluid. Static and dynamic load levels influence bearing stiffness. For the value given above, a range of \pm 50 percent or more can be expected depending upon design details and other factors like preload level. Variations certainly exist in specific designs but these are primarily aimed at techniques to tailor the local structural stiffness to accommodate more application unique needs such as tolerance to misalignment, thermal gradients, shaft centrifugal growth and other factors.

A careful review of the literature shows that foil bearing load capacity performance has improved by a factor of three or four when comparing today's most advanced designs to early, but more primitive, bending dominated bearings [12]. While this improvement in performance is significant, when compared to other technological advances, such as computer 
memory storage density, foil bearing load capacity gains appear quite modest. Nonetheless, based upon load capacity, advanced foil bearings are well suited for many applications that have yet to be commercialized, such as propulsion gas turbines. A broader understanding of the manufacturing process may facilitate their application.

The present paper lays out the publicly available manufacturing information in order to establish a foundation upon which interested practitioners may begin understanding, manufacturing, developing and eventually applying this bearing technology to future products.

\section{Foil Bearing Design and Construction}

Figure 2 shows cross section sketches of the two most prevalent types of foil bearing designs in use. Of these, the "bump" foil bearing (fig. 2(b)) type is described most completely in the open literature. Its early development was largely sponsored by various government agencies such as the DOD, DOE and NASA [17-20]. The "leaf type" foil bearings were originally developed by Garret-AiResearch (now Honeywell) using corporate resources. Although government support helped refine leaf foil bearings, manufacturing details for this type of bearing are limited. The only other widely commercialized and patented foil bearing design, by Capstone Turbines, was developed solely with non-public resources. The Capstone bearings employ a spring structure based upon perforated flat foils which form springs when installed inside curved and shaped bearing housings [21]. Since little information regarding bearing manufacturing and dimensions are publicly known for both the leaf type foil bearings and the Capstone perforated type foil bearings, this paper considers the bump-type designs.

A more detailed description of foil bearing history and the relationship between elastic design complexity and performance can be found in reference 12. That paper also introduces a simple, first principles and empirically based "Rule of Thumb" model for estimating bearing load capacity. In the present effort, both first and second generation bump type foil bearings are designed, manufactured and tested in order to demonstrate the effects proper elastic stiffness design of the foils can have on bearing performance.

\section{Foil Bearing Design and Fabrication Tooling}

Foil bearing designs have progressed through three distinct phases or generations since the introduction of the first practical bending dominated designs of the 1960's. These first generation (Generation I) designs are characterized by having a uniform simple elastic foundation with uniform stiffness properties. Generation I foil bearings exhibit load capacities approximately equal to rigid gas bearings of similar size. Second generation (Generation II) foil bearings have a more complex elastic foundation in which the stiffness is tailored in one direction, for example axially, to accommodate some environmental phenomena such as shaft misalignment or leakage of hydrodynamic fluid from the foil edges. These Generation II foil bearings exhibit load capacities approximately twice that of Generation I bearings. Third Generation bearings, with very complex elastic foundations, have stiffness that is tailored in two directions, often axial and radial. This level of design flexibility enables accommodation of edge effects and the ability to optimize bearing stiffness for varying loads. Generation III foil bearings have been shown to have load capacities three to four times greater than primitive Generation I bearings.

Several open literature publications and government technical project reports give detailed geometric descriptions of first and second-generation bump foil bearings [19,22]. Combined with companion patent information, these sources provide a reasonable starting point for the bearing designs manufactured and tested in the present effort $[10,11]$. To expedite the manufacturing effort, an adaptable tooling set was designed which enabled a variety of bearing types (first and second generation) to be conveniently fabricated. To minimize the need for multiple sets of tools, specific foil dimensions were not dictated a priori, but rather a specific tooling geometry, described in the following section, was designed which resulted in several different bearings with varying dimensions. The primary goal of this project is to demonstrate the manufacturing process for foil gas bearings and how the bearing elastic foundation characteristics affect general bearing performance. No attempt is made to optimize bearing performance.

The basic elements of the manufacturing process consist of three primary steps. The first is to cut annealed foils to size. This is followed by forming either by rolling for the top foils or pressing against a corrugated tool steel die. The final step is to heat treat the formed foils to develop favorable spring properties and strength.

Figure 3 shows the tooling developed for manufacturing the bump foil. The general tooling configuration and methodology is derived from reference 19. The tooling was fabricated from hardened and ground 15-5 PH stainless steel plates. First the top and bottom were ground flat and parallel, then the parts were cut and shaped using the wire Electrode Discharge Machining (EDM) process. Conventional machining utilizing milling could have been used but the wire EDM process allows convenient and accurate cutting of the bump patterns and results in a smooth surface finish needed to assure smooth bump foils.

The bump geometry was developed using bearing dimensions reported in several papers as a starting point $[19,22]$. Each bump in the bump dies has a width of $2.5 \mathrm{~mm}$ and a depth or height of $0.5 \mathrm{~mm}$ and are separated by a flat segment with a length of $0.6 \mathrm{~mm}$ as shown in figure 3 . In practice, the top surface of the bump foil follows the contour of the bump die regardless of the thickness of the foil used. For these bearings, a fine-grained precipitation harden-able nickel based super-alloy was used for the foils. Both the bump and top foils 
were made from sheet approximately $0.100 \mathrm{~mm}$ (0.004 in) thick. Thicker foils will result in higher stiffness but at the expense of lower compliance. Based upon the authors' earlier experience with partial arc foil bearings, this foil thickness is a good starting point giving adequate stiffness while retaining good formability and compliance [23]. No effort was made to optimize or predetermine the bearing geometry for particular bearing performance characteristics. The bearing stiffness is largely dictated by the foil thickness and bump design. Since both the Generation I and Generation II bearings use the same basic bump geometry their stiffness is expected to be similar.

The Generation I bearings tested were made using the tooling configured as shown in figure 3. The resulting bearings had uniform bump geometry as shown in figure 4(a). All of the test bearings' inside diameters were sized for $35 \mathrm{~mm}$ (1.375 in) or $38 \mathrm{~mm}$ (1.5 in) shafts. The Generation II bearings tested were also made with the tooling shown in figure 3 however, the centermost bump die was rotated $180^{\circ}$ which resulted in a one-half pitch staggering of the center bump strip as shown in figure 4(b). This design, taken directly from the patent literature, claims to provide a more uniform elastic foundation for the top foil and accommodate misalignment and other edge effects better than less complex Generation I bearings [10].

Figure 5 shows the tooling set-up in the hydraulic press used to form the bump foils. The general forming process begins by cutting the foil to length (and width) using metal shears and/or wire (EDM). When making bump foils for the Generation II bearing, slits must be cut into the foil prior to forming. Figure 6 shows a photograph of a Generation II bump foil prior to forming. For the slit foils, channels approximately $1 \mathrm{~mm}$ wide were cut using wire EDM. After being cut to the desired dimensions, the foils were placed on top of the bump tooling and held in place with a small strip of adhesive tape placed over the flat edge of the foil. A layer of rubber, approximately $5 \mathrm{~mm}$ thick, was then placed on top of the foil over which a ground tool steel plate was laid. Finally, the hydraulic press was loaded onto the top plate.

A series of experiments were undertaken to determine the pressing load necessary to achieve adequate bump foil forming. Figure 7 and table I show the results. For the experimental set-up used, loads less than $133 \mathrm{kN}(30,000 \mathrm{lb})$ resulted in incomplete bump formation. Loads exceeding $177 \mathrm{kN}$ $(40,000 \mathrm{lb})$ resulted in neither an improvement in the formed bump geometry nor its consistency but did result in rapid damage of the rubber layer. Therefore a load of $177 \mathrm{kN}$ $(40,000 \mathrm{lb})$ was selected for subsequent forming. This translates into a unit load of about $28 \mathrm{MPa}(4,000 \mathrm{psi})$ on the foils. This value compares favorably with the yield strength of the foil that is obtained in the fully annealed state from the rolling mill [24].

After cutting the foils and forming the bumps, the next step in the process is to form the foils into the circular shape of the bearing. The top foil is curled by passing it through a simple hand cranked roller such as the one shown in figure 8 . The bump foil, on the other hand, cannot be passed through a smooth roller, as this would deform the bumps. However, the foil at this stage is still in its annealed condition and can be readily formed by simply wrapping it carefully over a mandrel of suitable size. It was found that hand wrapping the bump foil over a mandrel with a diameter approximately two third's that of the final desired bearing diameter worked well. Following the forming steps, the foils must be prepared for precipitation hardening heat treatment.

There are many different heat treatments for Inconel X-750 that will give satisfactory results [24]. All of the heat treatments achieve strengthening through the precipitation of various hardening phases, typically carbides. The grain size, precipitate size and distribution as well as grain boundary chemistry control final material properties sometimes in subtle ways. Since the foils, especially the bump foil, function as springs, foil bearing heat treatments are generally selected to maximize spring properties (elastic modulus) and fatigue strength. Table II lists several heat treatments generally suitable for foil bearings. For maximum high temperature spring properties, the manufacturer recommends the so-called "triple heat treatment".

This heat treatment includes the solution anneal at $1150{ }^{\circ} \mathrm{C}$ $\left(2100{ }^{\circ} \mathrm{F}\right)$, usually conducted at the mill prior to foil cutting and forming, followed by a long duration ( $24 \mathrm{hr}$ ) stabilization heat treatment $843{ }^{\circ} \mathrm{C}\left(1550{ }^{\circ} \mathrm{F}\right)$ finishing with a long $(20 \mathrm{hr})$ precipitation heat treatment conducted at $704{ }^{\circ} \mathrm{C}\left(1300{ }^{\circ} \mathrm{F}\right)$. Each step is followed by a cool down to room temperature. Since the foil material is thin, it has a relatively large surface area to volume ratio compared to other forms like bar stock. Therefore during heat treatment, care must be taken to prevent excessive oxidation of the foil by the furnace atmosphere as this may lead to the compositional depletion of minor but important constituents in the alloy.

To preclude oxidation, foil bearings are typically heat treated in inert or vacuum environments. Alternately, a heat treatment conducted at a lower temperature, $\sim 650{ }^{\circ} \mathrm{C}(\sim 1200$ $\left.{ }^{\circ} \mathrm{F}\right)$, can be selected, although less desirable mechanical properties may result. For instance, a simple four-hour air heat treatment at $650{ }^{\circ} \mathrm{C}\left(1200^{\circ} \mathrm{F}\right)$ provides adequate strengthening and properties retained to $371{ }^{\circ} \mathrm{C}\left(700{ }^{\circ} \mathrm{F}\right)$ in use. This low cost heat treatment would suffice for lightly loaded bearings operating at relatively low temperatures in applications that are cost sensitive. Lastly, the manufacturer's materials manual strongly suggests that springs be heat-treated using an arbor placed snugly inside the spring during the heat treatment [24]. This helps prevent sagging and helps the spring retain its coldformed shape during the high temperature processing. For this bearing project two fixture methods were used.

In the first method, a "C" shaped roll was formed along one edge of the foils using a split roll pin as a tool. Next, the top and bump foils were then nested and wrapped around Inconel $\mathrm{X}-750$ test shafts and held in place with nickel-chrome wires. To prevent the foils sticking upon each other, a light spray coating of pure boron nitride was found to be helpful. Only heat treatments that included the solution treating 
$\left(1150^{\circ} \mathrm{C} / 2100^{\circ} \mathrm{F}\right)$ step following forming required the boron nitride as a release agent. Figure 9 shows the parts ready for heat treatment. After the heat treatment, the bearing is constructed by sliding the " $\mathrm{C}$ " shaped edges of the foils into grooves machined into the bearing shell as shown in figure 10 .

In the second method, the top and bump foils are spot welded into a machined Inconel X-750 sleeve that then forms the bearing's outer support or shell. Spot welding is a process often used in the manufacture of foil bearings and is typically done after heat treatment. However, welding alters the structure and metallurgy of foils and these welds, if not heat treated, can be an initiation site for degradations like fatigue cracks [24]. For the test bearings, the welding is done prior to heat-treating so the welds develop favorable metallurgy along with the foils. Prior to heat-treating, an arbor is slipped inside the foils to help them retain their shape during processing. Figure 11 shows a prepared, spot-welded bearing prior to heattreating.

\section{Testing}

Following manufacturing, the bearings are tested on a high speed, high temperature foil bearing test rig to ascertain their general performance characteristics such as power loss and load capacity. Reference 25 describes the test rig and procedure in detail. Prior to testing, a NASA PS304 coated shaft is installed on the rig and ground and balanced in place to ensure a smooth running surface. NASA PS304 is a high temperature solid lubricant coating deposited by the plasma spray process. It is described in reference 26 and provides a smooth, low friction surface for the foil bearings. The bearing is placed on the shaft and the shaft diameter is sized to provide a low spring preload (interference fit) of around $3.4 \mathrm{kPa}(0.5 \mathrm{psi})$ ) with the bearing. The preload level is determined by conducting breakaway torque measurements at varying deadweight loads using the method described in the literature [15]. Reference 27 describes in more detail the effect preload level, influenced by shaft diameter, has on bearing performance.

In the present study, the bearing load capacity and power loss are measured at $25{ }^{\circ} \mathrm{C}$. Before bearing performance is measured however, the bearings are broken-in at elevated temperature to achieve smooth surfaces conducive for good gas bearing operation. The break-in process consists of repeated start-stop cycles under a moderate $(14 \mathrm{kPa}(2 \mathrm{psi}))$ static load at a temperature above $400{ }^{\circ} \mathrm{C}$. Typically 500 startstop cycles at $500{ }^{\circ} \mathrm{C}$ are sufficient to develop well-polished surfaces rich in solid lubricants needed for good bearing performance. The break-in process and the effects of the roughness on bearing performance are described in detail in references 26 and 28. Figure 12 shows a photograph of a NASA PS304 coated shaft after the break in process. The surface finish of the coating improves from around 0.5 to $0.1 \mu \mathrm{m}$ (16 to $4 \mu \mathrm{in}$.) rms during the process.

Earlier extensive research on foil bearings shows that bearing performance can be categorized based upon the complex- ity of the elastic foundation and its tailoring for environmental and system factors such as shaft misalignment and thermal growth. Early first generation bearings (fig. 2) have simple elastic foundations with a uniform stiffness and exhibit load capacity coefficients, designated as "D", of 0.2 to 0.3 using the equation developed in reference 12. By splitting the bump foil and staggering the bump strips, the bearing can better accommodate shaft misalignment, for example, and is expected to show improved load capacity coefficients of 0.4 to 0.6 . These second generation bearings are depicted in figure 13. To measure the load capacity coefficient, the bearing is run at a constant high speed while load is added using a cable system until the bearing can no longer run with low and stable torque. Rising, unsteady torque is a sign that the load capacity has been reached. This procedure is repeated at least three times at varying speeds to ascertain an average D coefficient [12].

To measure power loss, the cable loading system is replaced with well balanced deadweight bearing holders made from high-density tungsten alloys. These "donut" shaped bearing holders, shown in figure 14 , are used to measure torque accurately without any errors introduced, however small, from a cable loading system such as the one used for the load capacity tests. Reference 13 describes the power loss measurement procedure in detail. An approximately $3 \mathrm{~kg}$ total mass is used as the dead load and speeds were varied from 12 to $50 \mathrm{krpm}$ while bearing torque was measured. Power loss was then calculated as the product of the speed and the torque.

\section{Bearing Performance Results}

Table III shows the bearing load capacity results for the Generation I and II bearings that were manufactured and tested. The simple Generation I bearing exhibited an average load capacity coefficient of $0.27 \pm 0.03$ and the more complex Generation II bearing showed an average load capacity coefficient of $0.54 \pm 0.05$. The error represents one standard deviation of the data for the repeated tests. These results are within the range of expected values for bearings of this type based upon previous testing of similar Generation I and more advanced Generation III bearings obtained through commercial sources that typically exhibit load capacity coefficients of 0.8 to 1.0 .

Figure 15 plots bearing power loss as a function of speed for selected test bearings. Again, the data agree well with similar data measured previously using bearings of similar designs [19]. The difference in the magnitude of the power losses for the bearings shown is likely the result of differences in bearing preloads, the Generation I bearing had a higher preload than the Generation II bearing.

Figure 16 shows the surface of the top foil of Generation I and II test bearings following the load capacity test. The evidence of localized rubbing, which can occur during such extreme testing, appear as axial "tiger stripes" or bands. These wear characteristics indicate that the top foil is indeed supported by the bumps and that the gas pressure film forces the 
foil to sag away from the shaft between the bumps [22]. If foil sag had not occurred during these high load tests, the wear marks would have covered a wider circumferential area and not manifested themselves as distinct bands. Despite the observation that foil sag occurred at high loads, both the Generation I and II bearings performed predictably.

\section{Discussions}

These results indicate that the information available in the open literature provides an acceptable technical path for the basic design, manufacturing and testing of compliant surface foil gas bearings. However, the bearings manufactured and tested in this project are not considered the latest and most advanced, Generation III, designs. The most modern bearings have elastic foundations in which the stiffness can be spatially tailored in at least two directions. Commercially available Generation III bearings have been shown to display load capacity coefficients nearly double that of Generation II bearings and triple that of the earliest Generation I bearings $[12,25]$.

Two major features are usually found in third generation bearings. These features are a mechanism to minimize top foil sag between support points (e.g., bump foil peaks) and radial stiffness that varies according to deflection. Figure 17 shows a drawing from the patent literature in which an additional smooth foil layer is placed between the top and bump foils [29]. This "stiffener" layer prevents top foil sag and excessive side leakage of the gas lubricating film. Tests of this type of foil bearing have yielded load capacity coefficients of around $\mathrm{D}=1.0$ [12]. Figure 18 shows the cross section drawing from another recent patent of a bearing in which two bump layers are employed [30]. Under light loads, the bumps of a relatively soft bump foil layer contact the underside of the top foil giving the bearing a low stiffness. This low stiffness is conducive to generating a lubricating hydrodynamic fluid film at a low surface speed. At high loads and speeds, the increased resulting hydrodynamic gas pressure deflects the foils more, engaging the underlying stiffer bump foil layer. Thus the elastic foundation provides a higher stiffness better matched to the higher stiffness of the gas film that forms under these conditions. This gives the bearing better load capacity and increased stiffness. Often, the most advanced bearings include many of these features to achieve adequate performance for demanding applications.

It should be noted that this paper does not include the design, manufacture and testing of Generation III bearings, most of which are protected by patents. The primary purpose of this paper is to review the general basis of foil gas bearing design and manufacture and to demonstrate that the public literature contains sufficient information to practice the art. However, to the authors' knowledge, there is no publicly available information on the design dimensions of third generation foil gas bearings. The patents currently offering protection for Generation III foil gas bearings do disclose the design features that give these bearings superior performance but do not reveal the specific dimensional details necessary to duplicate such hardware [29-32].

Nonetheless, the information provided here can be used to manufacture less advanced foil gas bearings that may be suitable for a wide variety of turbomachinery applications. For instance, turbo-compressors used for air cycle machines utilize Generation I foil bearings [5]. The market need for bearings for commercial blowers, expanders and pumps especially stationary devices which do not experience environmental loads (e.g., shock loads) may be satisfied with such bearings.

In addition, it is expected that once a greater number of research efforts are directed at foil bearing design and manufacturing, additional innovations including novel approaches to manufacturing foil bearings will ensue.

\section{Summary Remarks and Conclusions}

First and second-generation foil gas bearings were designed and manufactured based upon information available in the open literature. A novel tooling technique was employed to allow simple modification to the bump foil design without manufacturing all new tooling. Bearings manufactured using this tooling were tested for their performance and compared to data in the literature and to values predicted by modern "Ruleof-Thumb" models. Good agreement was found between experiment, literature and model prediction data.

It was shown that there is a direct relationship between the complexity of the bearing elastic support structure and bearing performance. Bearings with simple designs provided the lowest load capacity, an important performance criterion. Bearings in which the foundation was tailored to accommodate system level phenomenon such as shaft misalignment provided load capacities nearly twice that of the simpler bearings. It is anticipated that these results will better explain the need for and value of commercially available, advanced geometry bearing designs for successful application to demanding turbomachinery systems. 
TABLE I.-EFFECTS OF FORMING LOAD ON DEGREE OF BUMP FORMATION

\begin{tabular}{|c|c|}
\hline $\begin{array}{c}\text { Forming load, } \\
\mathrm{lb} \times 1000(\mathrm{~N})\end{array}$ & Results \\
\hline $10(44,480)$ & Slight permanent deformation \\
\hline $20(88,960)$ & Moderate deformation \\
\hline $30(133,440)$ & Moderate deformation \\
\hline $40(177,920)$ & Complete deformation \\
\hline $50(222,400)$ & Complete deformation \\
\hline $60(266,880)$ & Complete deformation \\
\hline
\end{tabular}

*Foil area: 1.5 by 6.0 in. $=38$ by $152 \mathrm{~mm}$

TABLE II.-POSSIBLE HEAT TREATMENTS FOR INCONEL X-750 USE FOR FOIL BEARINGS

\begin{tabular}{|c|c|c|}
\hline $\begin{array}{c}\text { Heat } \\
\text { treatment } \\
\end{array}$ & $\begin{array}{l}\text { AMS } \\
\text { no. }\end{array}$ & Remarks \\
\hline $\begin{array}{l}2100^{\circ} \mathrm{F}\left(1149^{\circ} \mathrm{C}\right) \\
\text { anneal }+ \\
1550^{\circ} \mathrm{F}\left(843^{\circ} \mathrm{C}\right) / \\
24 \mathrm{hr}, \text { A.C. }+ \\
1300^{\circ} \mathrm{F}\left(704^{\circ} \mathrm{C}\right) / \\
20 \mathrm{hr} \text {, A.C. }\end{array}$ & 5668 & $\begin{array}{l}\text { "Triple heat treatment" } \\
\text { Maximum high temperature } \\
\text { Spring properties to } 1200^{\circ} \mathrm{F} \\
\left(650^{\circ} \mathrm{C}\right)\end{array}$ \\
\hline $\begin{array}{l}1350^{\circ} \mathrm{F}\left(732^{\circ} \mathrm{C}\right) / \\
16 \mathrm{hr}, \text { A.C. }\end{array}$ & 5698 & $\begin{array}{l}\text { "Number one" temper, good } \\
\text { spring properties to } 1000^{\circ} \mathrm{F} \\
\left(538^{\circ} \mathrm{C}\right)\end{array}$ \\
\hline $\begin{array}{l}1200^{\circ} \mathrm{F}\left(650^{\circ} \mathrm{C}\right) / \\
4 \mathrm{hr} \text {, A.C. }\end{array}$ & 5699 & $\begin{array}{l}\text { "Spring" temper, good spring } \\
\text { properties to } 700^{\circ} \mathrm{F}\left(371^{\circ} \mathrm{C}\right)\end{array}$ \\
\hline
\end{tabular}

TABLE III.-LOAD CAPACITY OF TESTED BEARING

\begin{tabular}{|c|c|}
\hline Bearing & $\begin{array}{c}\text { Load capacity* coefficient, } \\
\text { D }\end{array}$ \\
\hline Generation I & $0.27 \pm 0.03$ \\
\hline Generation II & $0.54 \pm 0.05$ \\
\hline
\end{tabular}

*Load capacity tested at $25^{\circ} \mathrm{C}$ according to method described in reference 12 .

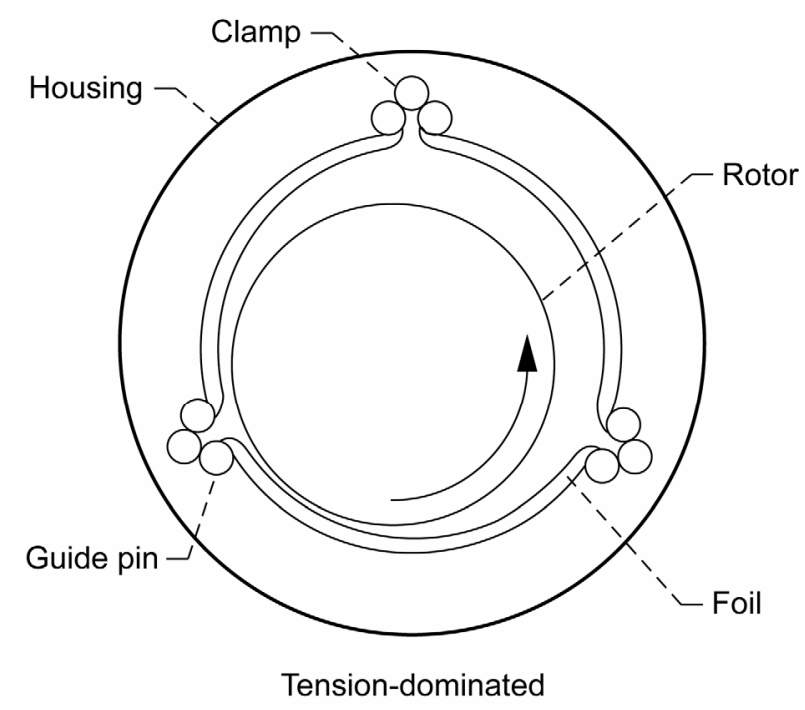

Figure 1.-Tension dominated "tape-type" early foil gas bearing. 

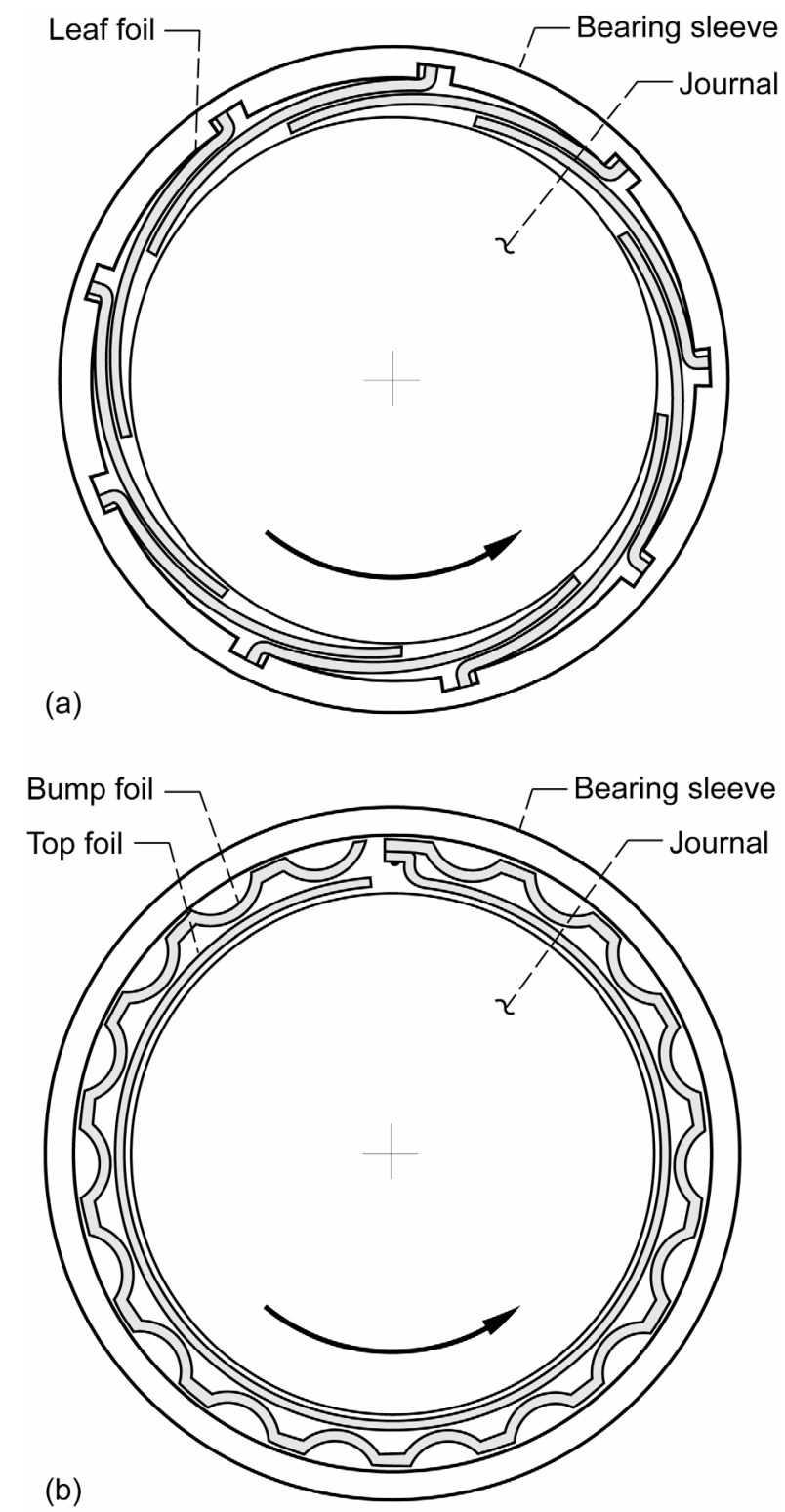

Figure 2.-Schematic example of first generation foil bearings with axially and circumferentially uniform elastic support elements. (a) Leaf-type foil bearing. (b) Bump-type foil bearing. 


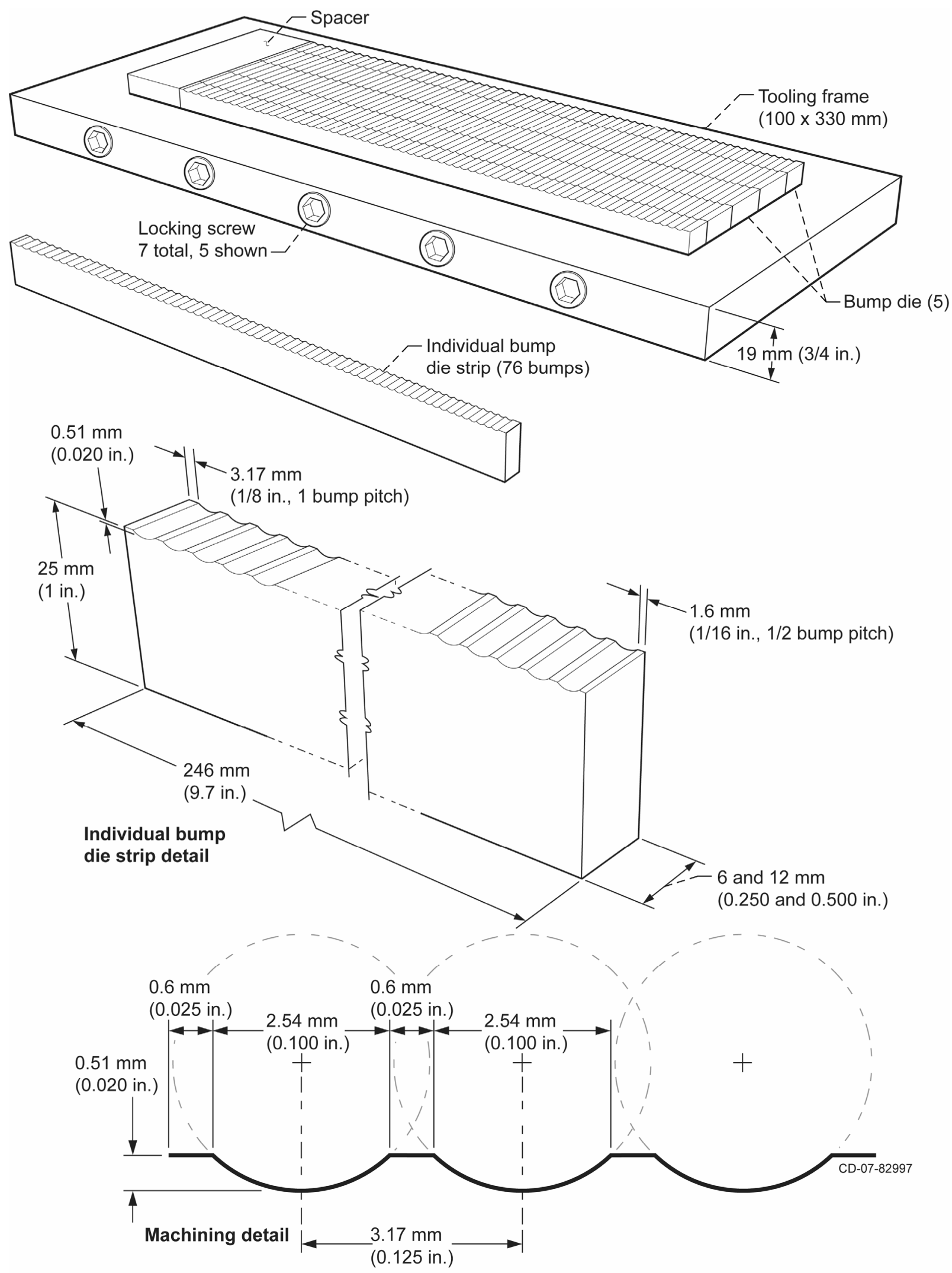

Figure 3.-Foil bearing tooling system used to form bump foils for both Generation I and Generation II foil gas bearings. 

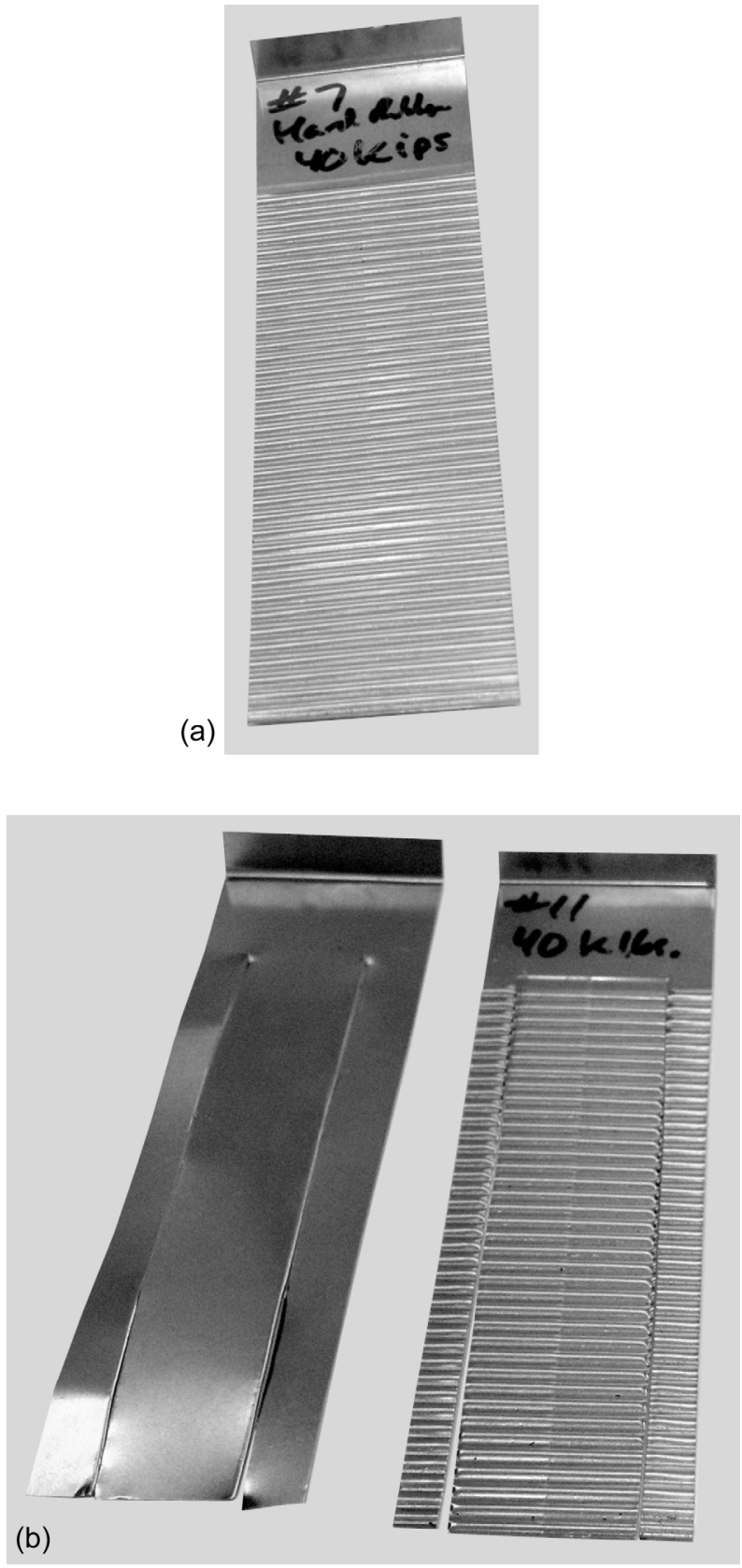

Figure 4.-(a) Photograph of Generation I bump foil after forming. (b) Photograph of representative split and staggered, Generation II bump foil prior to (left) and after (right) forming.
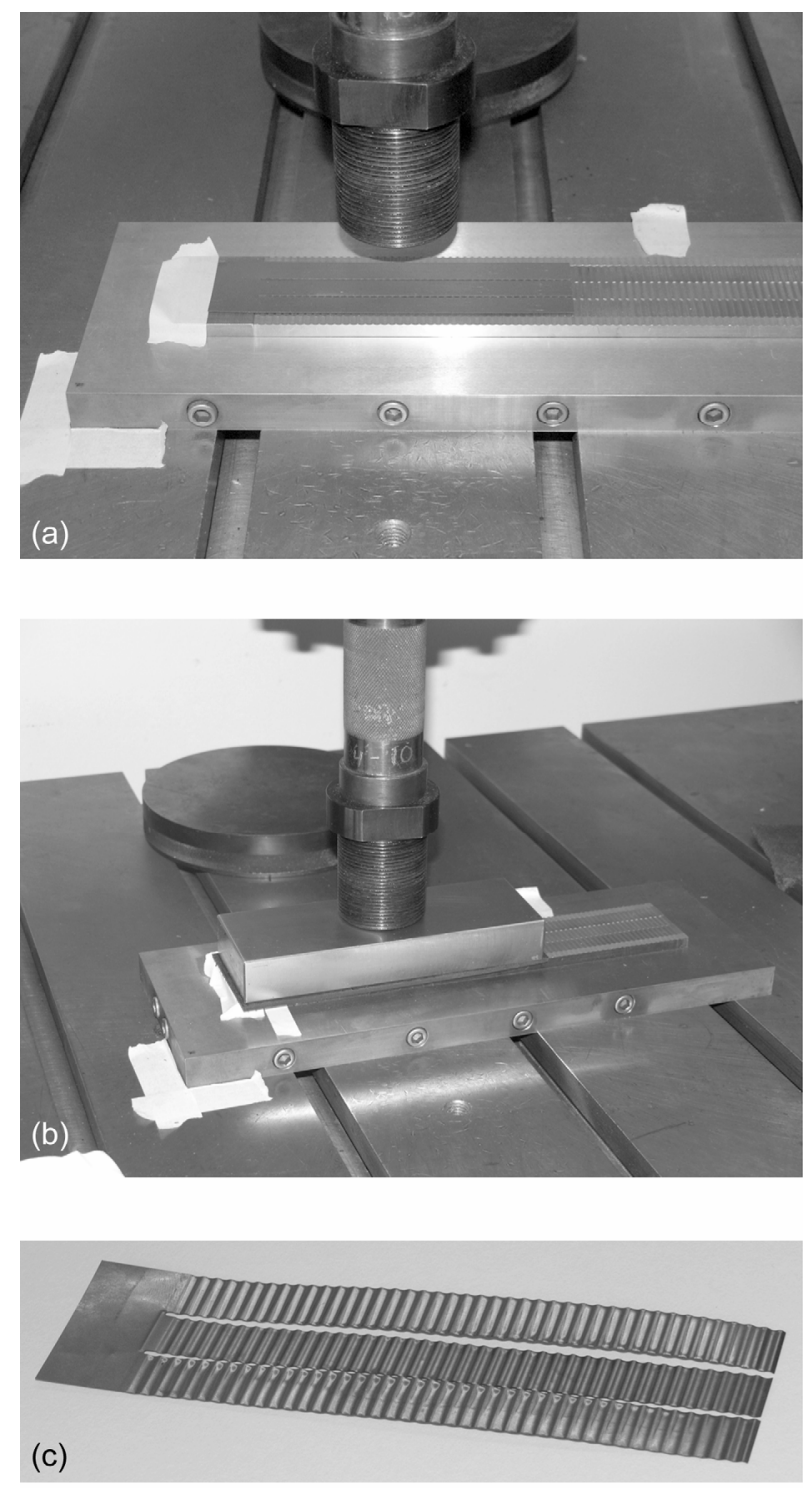

Figure 5.-(a) Photograph of Generation II bump foil positioned on tooling. (b) Photograph of complete tooling system during bump foil pressing operation. (c) Generation II bump foil after pressing. 


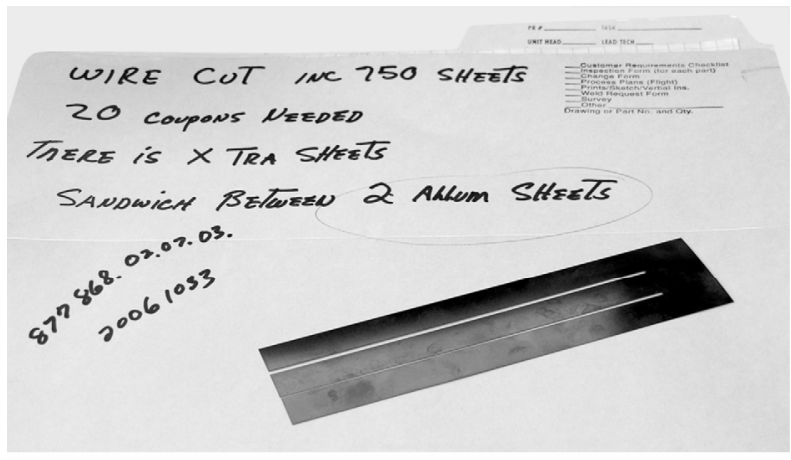

Figure 6.-Generation II bump foil with slits, prior to bump formation.

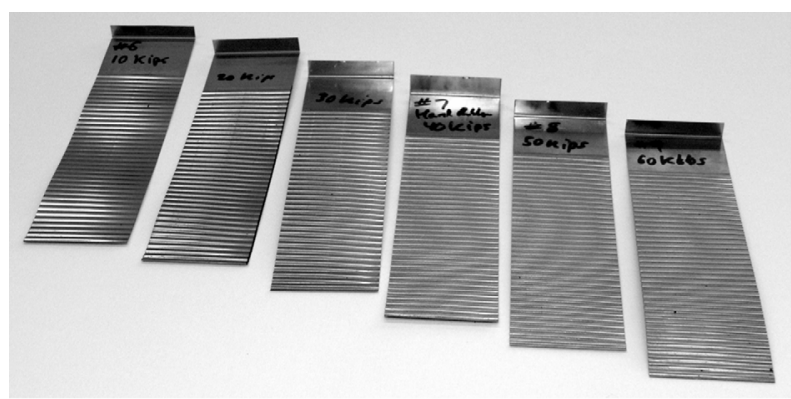

Figure 7.-Photograph of bump foils pressed at loads from $44.5 \mathrm{kN}$ (10 $000 \mathrm{lb}$ ) (left) to $266.9 \mathrm{kN}$ $(60000 \mathrm{lb})$ beyond $177.9 \mathrm{kN}(40000 \mathrm{lb})$ no changes are observed.

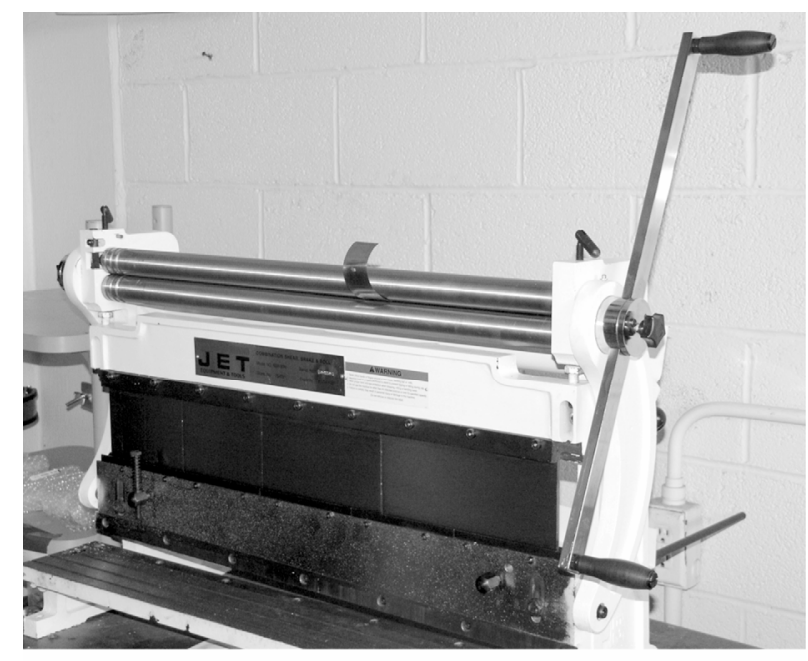

Figure 8.- Hand roller used to curve top foils prior to heat treatment.

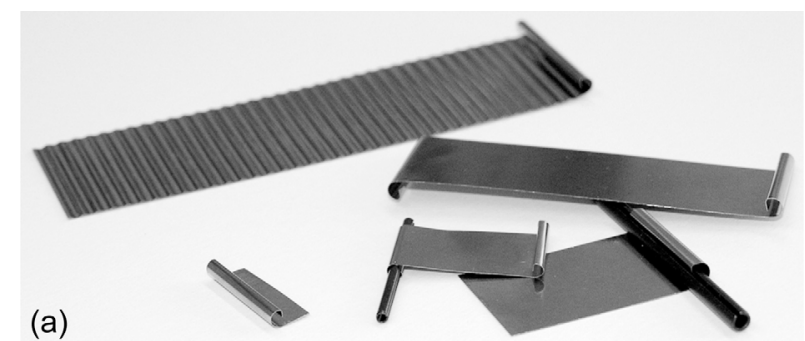

(b)

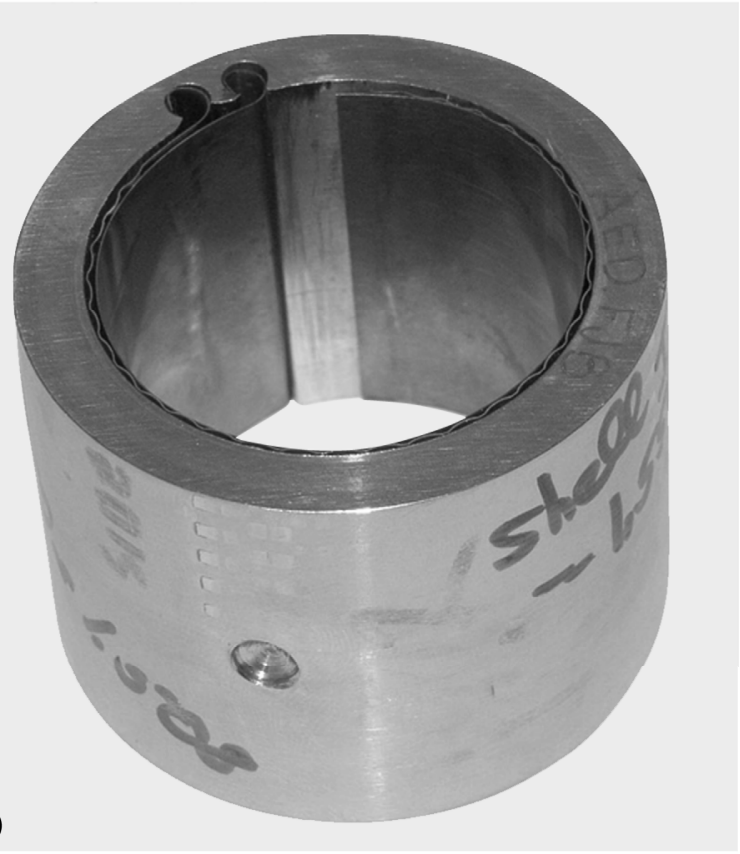

Figure 9.-Generation I foil bearing (a) and Generation II foil bearing (b), with formed "C" shaped ends, wrapped around mandrel shaft affixed with wires prior to heat treating. 

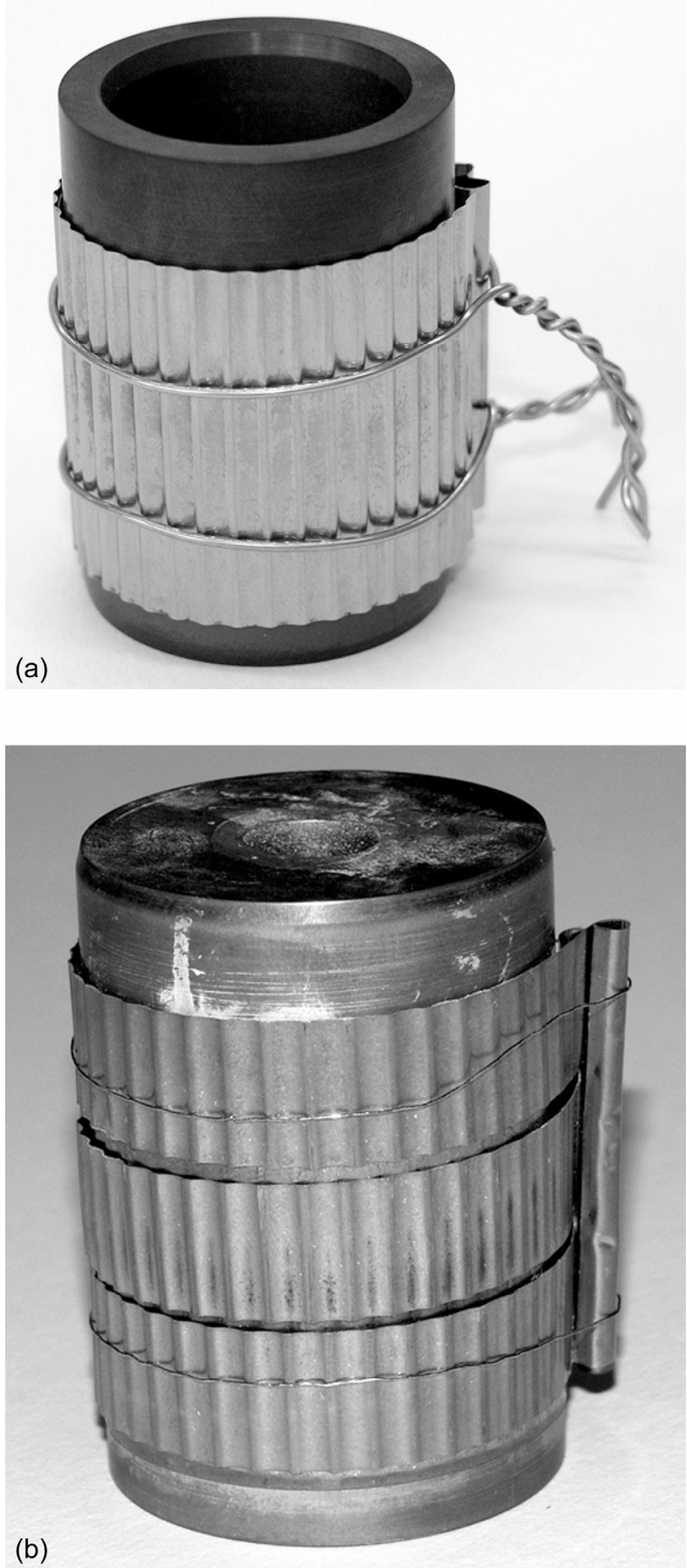

Figure 10.-(a) Generation I foil bearing wired to mandrel prior to heat treatment. (b) Generation II foils with formed " $\mathrm{C}$ " ends wrapped around mandrel shaft affixed with wires prior to heat treating.

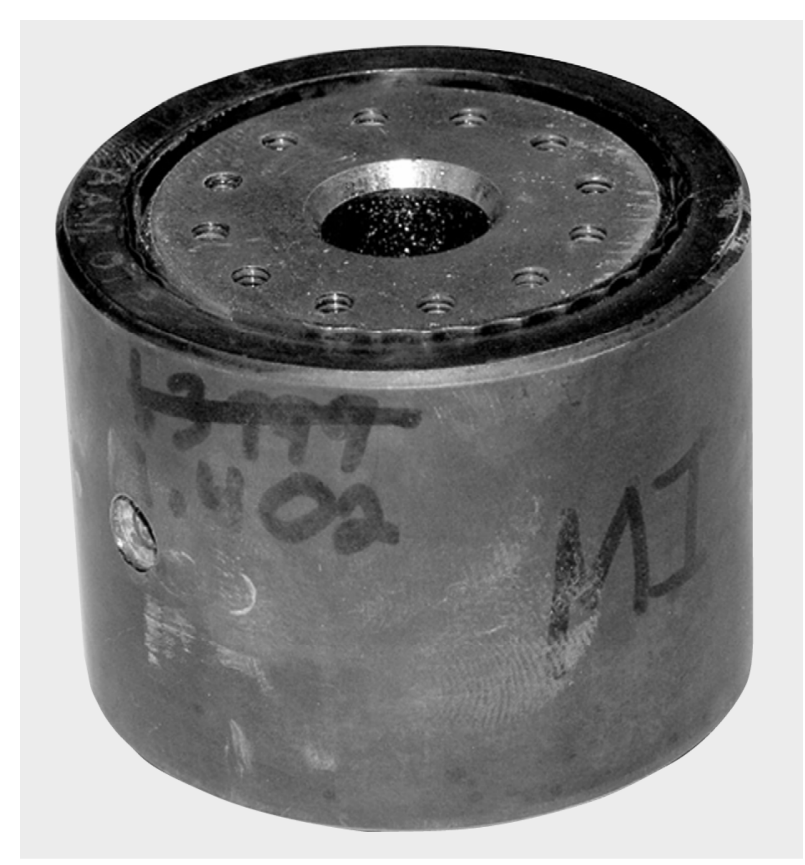

Figure 11.-Photograph of foils spot-welded to bearing sleeve with mandrel shaft prior to heat treating.

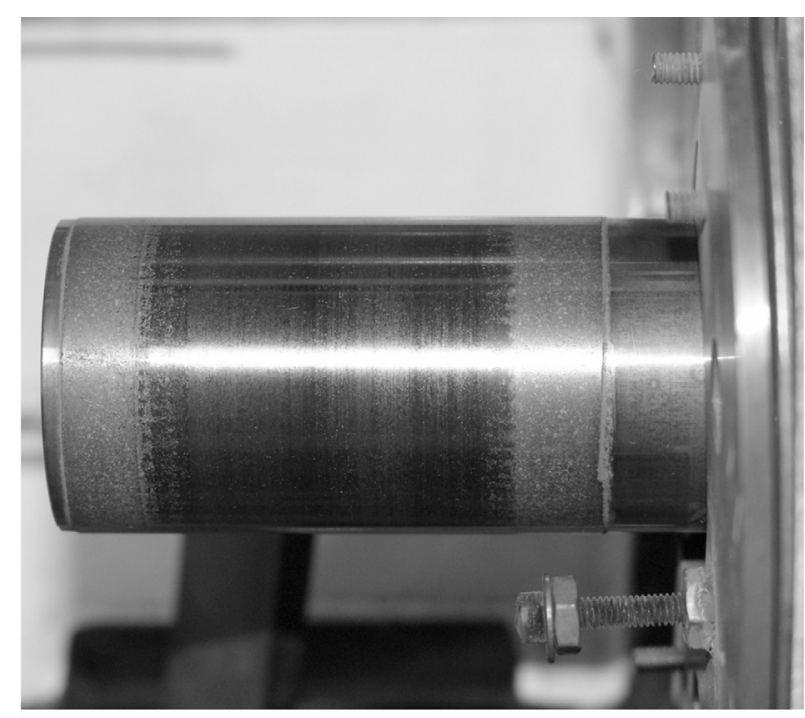

Figure 12.-Photograph of PS304 coated test shaft after 500 start/stop break in cycles at $500{ }^{\circ} \mathrm{C}$. Surface is smooth and glossy with a surface roughness of approximately $0.1 \mu \mathrm{m}(4 \mu \mathrm{in}$.) rms. 


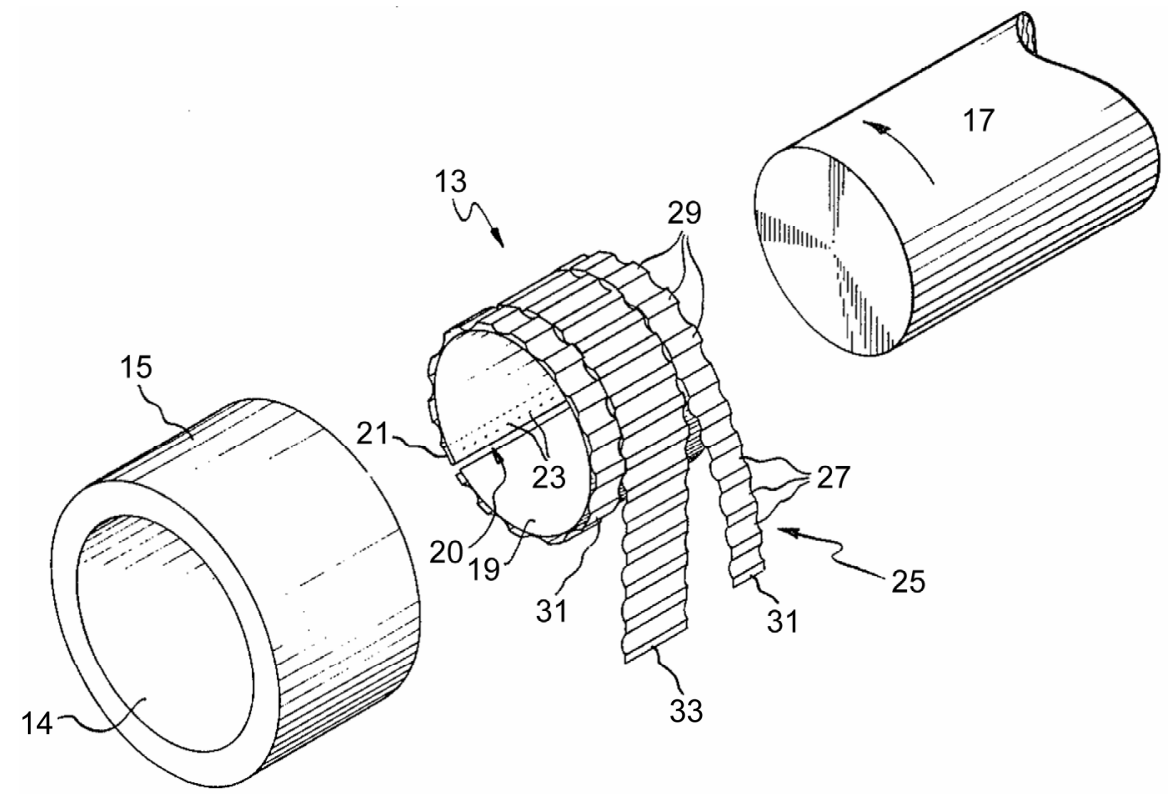

Figure 13.-Generation II bump foil bearing employing split bump foil design to control axial stiffness. From reference 11.

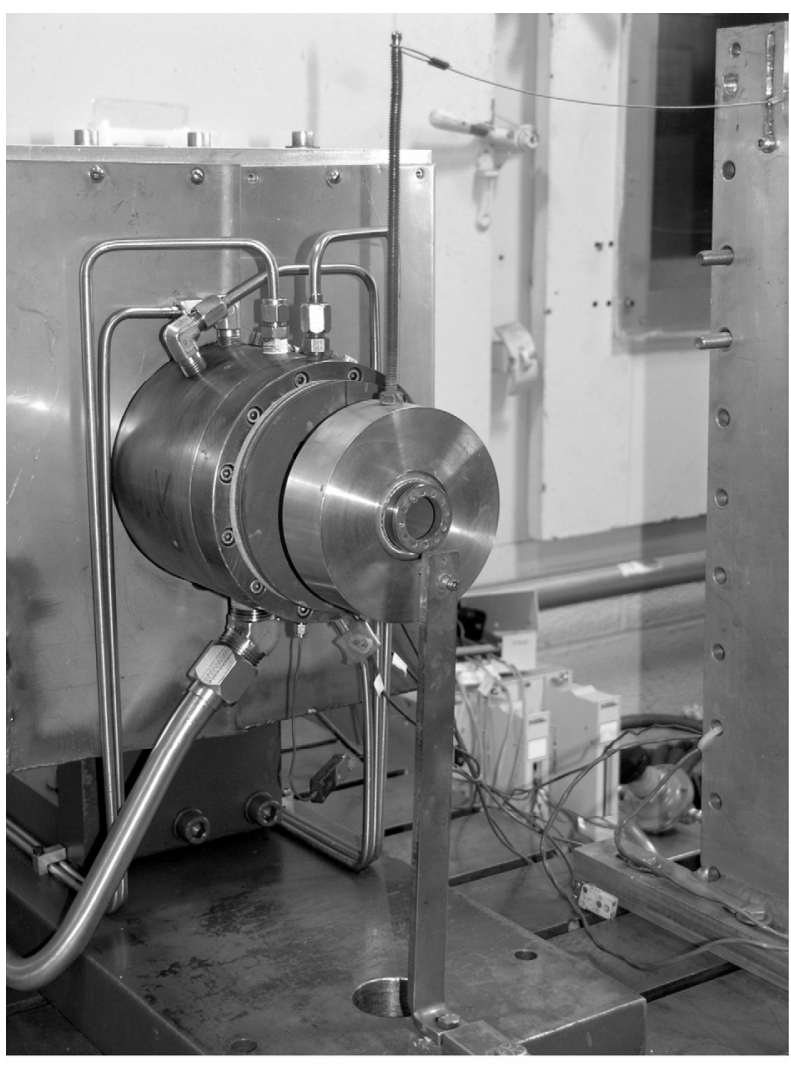

Figure 14.-Test set up for power loss measurements.
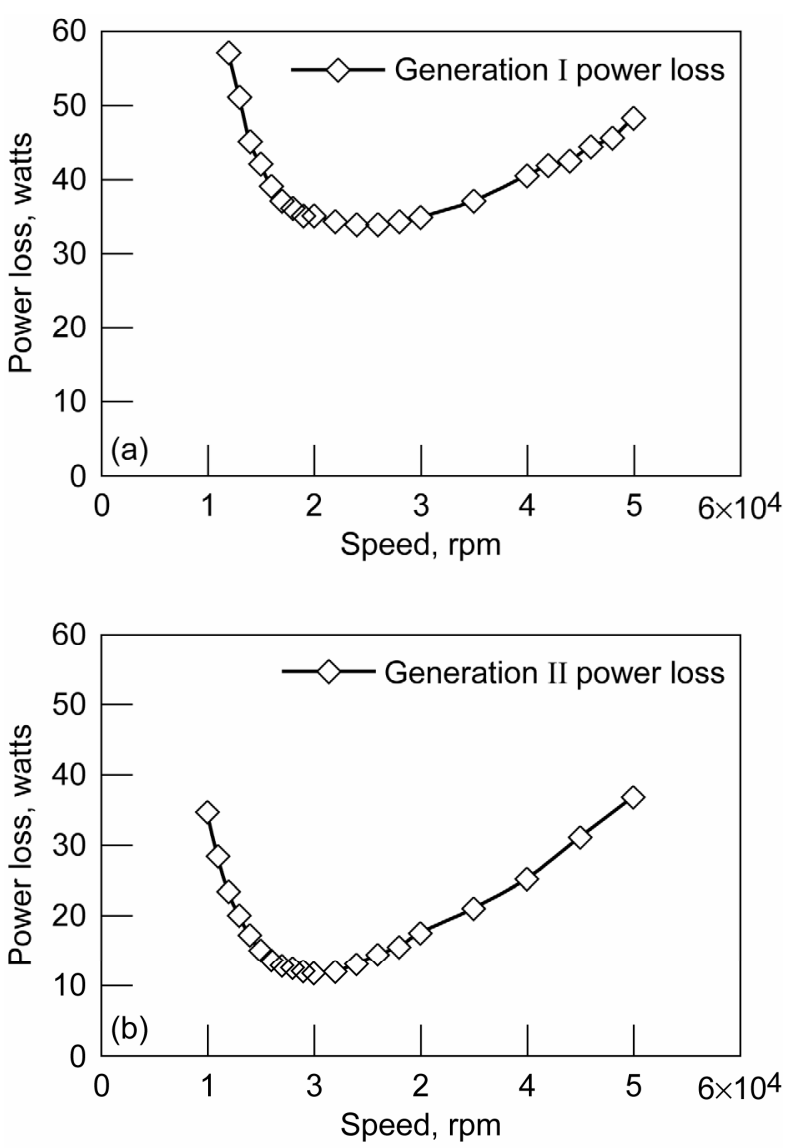

Figure 15.--Power loss versus speed for (a) Generation I foil bearing and (b) Generation II foil bearing. 

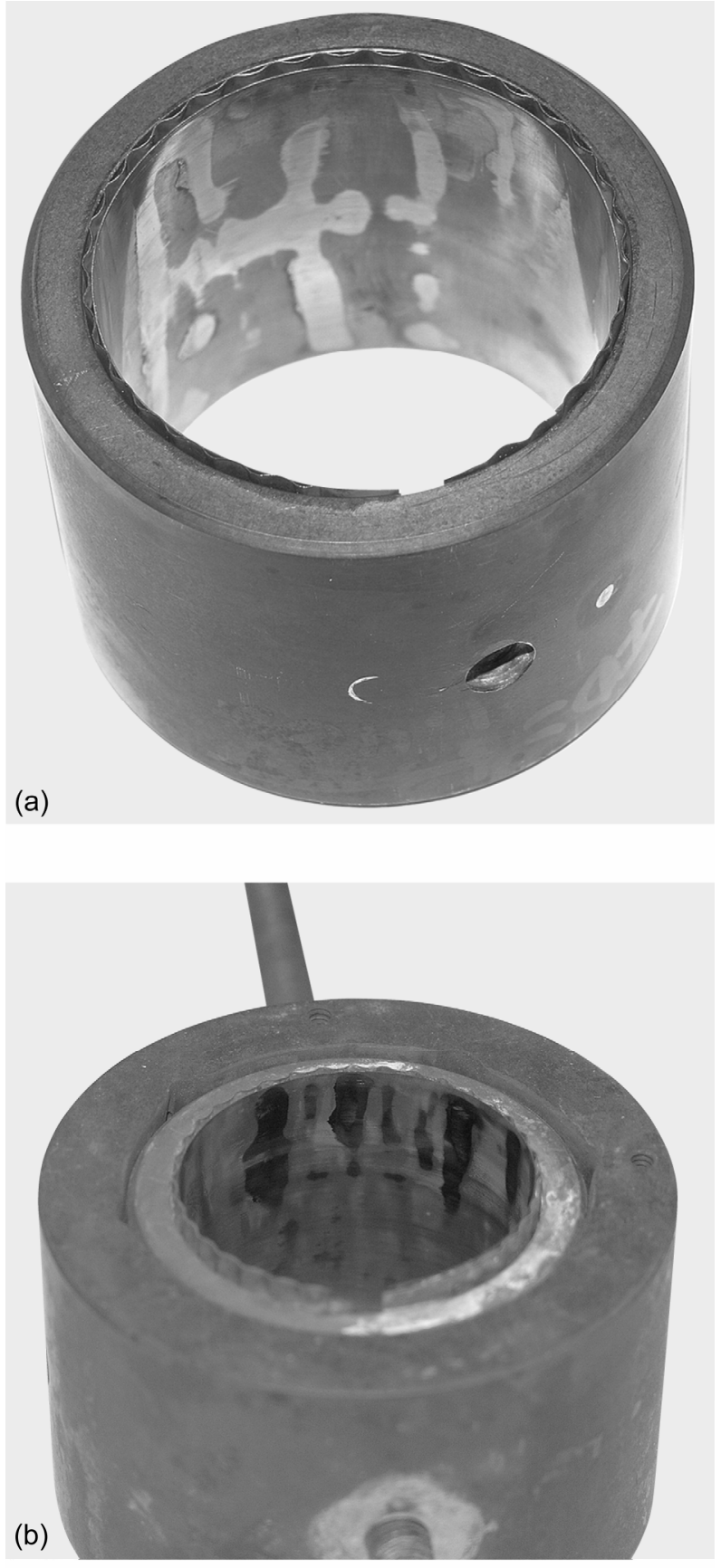

Figure 16.-(a) Generation I foil bearing after load capacity testing showing evidence of axial "tiger stripe" wear patterns indicative of foil sag between bumps. (b) Generation II foil bearing showing similar "tiger stripe" wear pattern.

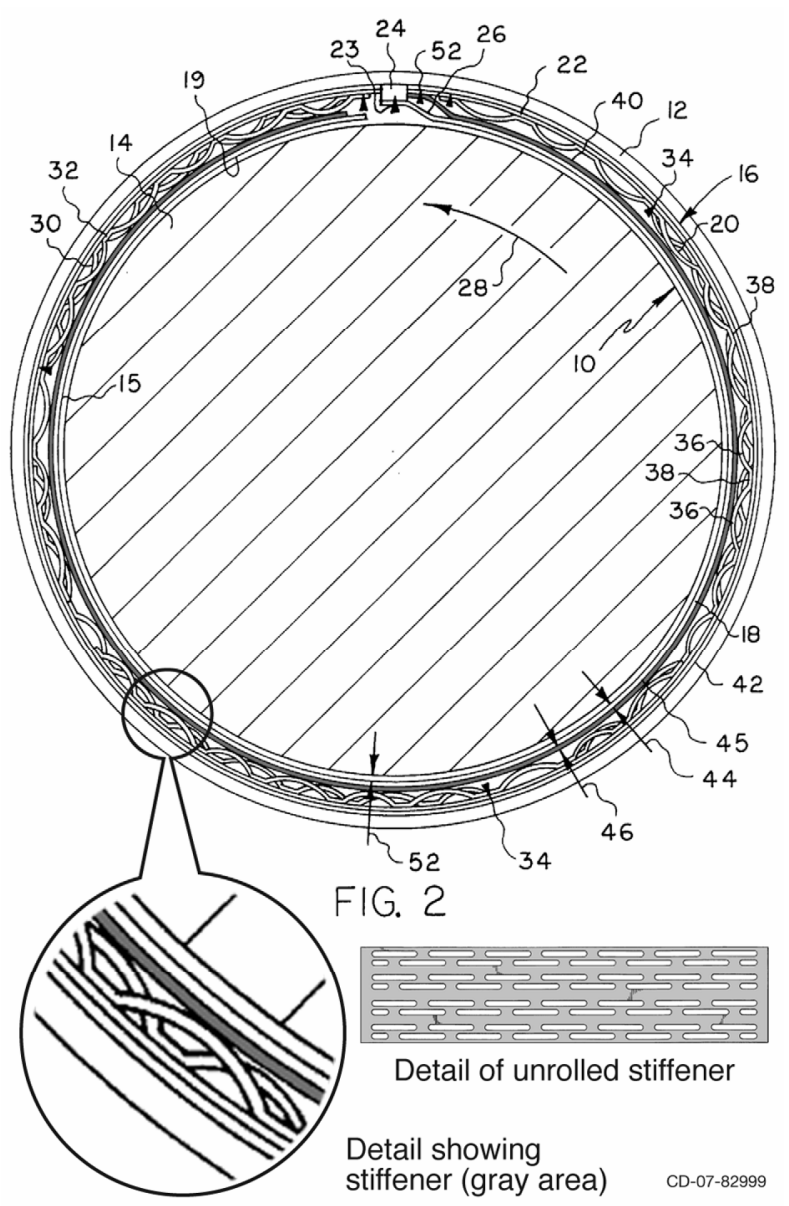

Figure 17.-Generation III foil bearing with stffener foil to prevent top foil sag. From reference 29.

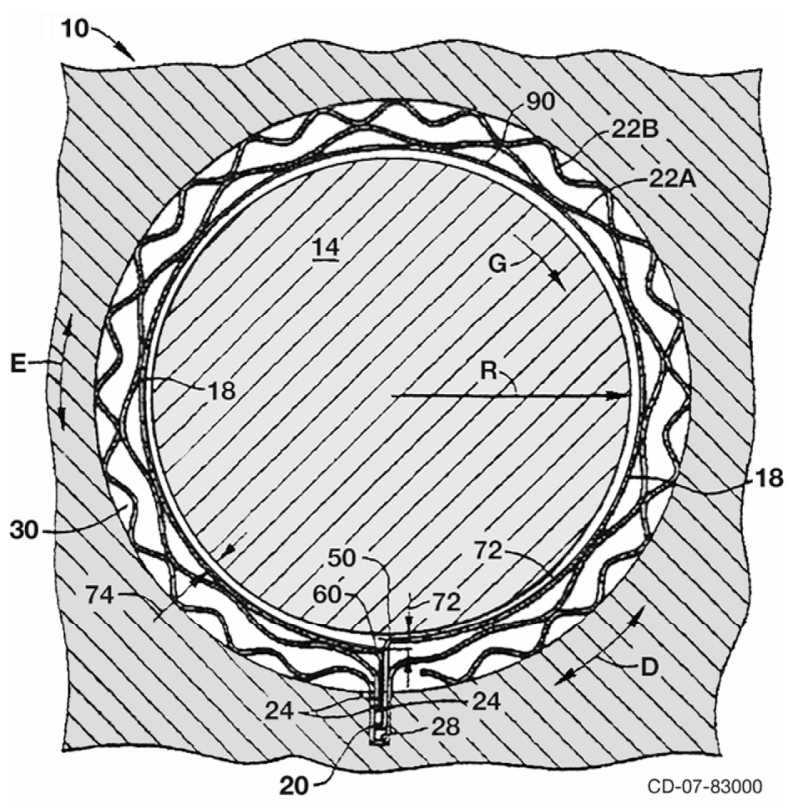

Figure 18.-Generation III double bump foil bearing design employing variable radial stiffness. From patent 6964522 reference 30 . 


\section{References}

[1] Gross, W.A. (1962), Gas Film Lubrication, John Wiley and Sons, New York, pp 138-114.

[2] Ma, J.T.S. (1965), "An Investigation of Self-Acting Foil Bearings," ASME J. of Basic Engineering, pp 837-846.

[3] Barnett, M.A. and Silver, A. (1970), "Application of Air Bearings to High-Speed Turbomachinery," SAE Paper 700720.

[4] Emerson, T.P. (1978), "The Application of Foil Air Bearing Turbomachinery in Aircraft Environmental Control Systems," in Proc. of the ASME Intersociety Conference on Environmental Systems, San Diego, CA, Paper No. 780-ENAS-18.

[5] Agrawal, G.L. (1990), "Foil Gas Bearings for Turbomachinery," in Proc. of $20^{\text {th }}$ Intersociety Conference on Environmental Systems, Williamsburg, VA, SAE Paper No. 901236.

[6] Lubell, D., DellaCorte, C., and Stanford, M.K. (2006), "Test Evolution and Oil-Free Engine Experience of a High Temperature Foil Air Bearing Coating," Proc. of GT2006: ASME Turbo Expo 2006, Barcelona, Spain, GT2006-90572.

[7] Heshmat, H., Walton, II, J.F., DellaCorte, C., and Valco, M. (2000), "Oil-Free Turbocharger Demonstration Paves Way to Gas Turbine Engine Applications," presented at the International Gas Turbine and Aeroengine Congress and Exhibition sponsored by ASME, Munich, Germany, 2000-GT-620.

[8] Suriano, F.J. (1981), "Gas Foil Bearing Development Program," U.S. Air Force Report No. AFWAL-TR-81-2095.

[9] Heshmat, H., Walton, II, J.F., and Tomaszewski, M.J. (2005), "Demonstration of a Turbojet Engine Using an Air Foil Bearing," ASME Paper GT-2005-68404, presented at the ASME Turbo Expo 2005, Power for Land, Sea and Air, Reno-Tahoe, NV.

[10] Miller, W.H. (1980), “Compliant Hydrodynamic Fluid Bearing With Resilient Support Matrix,” U.S. Patent No. 4,222,618.

[11] Gray, S. and Bhushan, B. (1981), "Support Element for Compliant Hydrodynamic Journal Bearings," U.S. Patent No. $4,274,683$.

[12] DellaCorte, C. and Valco, M.J. (2000), "Load Capacity Estimation of Foil Air Journal Bearings for Oil-Free Turbomachinery Applications," Trib. Trans., 43, 4, pp 795-801.

[13] DellaCorte, C., Radil, K.C., Bruckner, R.J. and Howard, S.A. (2006), "A Preliminary Foil Gas Bearing Performance Map," NASA/TM-2006-214343, Cleveland, OH.

[14] Newman, P. (1977), "Surface Coating for Machine Elements Having Rubbing Surfaces," U.S. Patent No. 4,005,914.

[15] DellaCorte, C., Lukaszewicz, V.L., Valco, M.J., Radil, K.C., and Heshmat, H. (1999), "Performance and Durability of High Temperature Foil Air Bearings for Oil-Free Turbomachinery," NASA/TM-1999-209187, Cleveland, OH. See also Trib. Trans., 43, 4, pp 774-780, October 2000.

[16] Howard, S.A., DellaCorte, C., Valco, M.J., Prahl, J.M.; Heshmat, H. (2001), "Dynamic Stiffness and Damping
Characteristics of a High Temperature Air Foil Journal Bearing," Trib. Trans., 44, 4, pp 657-667.

[17] Heshmat, H., Shapiro, W., and Gray, S. (1981), "Compliant Journal Bearing With Angular Stiffness Gradient," U.S. Patent No. 4262975.

[18] Suriano, F.J. (1981), "Gas Foil Bearing Development Program," U.S. Airforce Report No. AFWAL-TR-81-2095.

[19] Ruscitto, D., McCormick, J. and Gray, S. (1978), "Hydrodynamic Air Lubricated Compliant Surface Bearing for an Automotive Gas Turbine Engine: I-Journal Bearing Performance," NASA CR-135368.

[20] Wagner, C.E. and Pampreen, R.C. (1979), "Upgraded Automotive Gas Turbine Engine Design and Development Program Final Report," NASA CR-159671.

[21] Bosley, R.W. (1995), “Compliant Foil Hydrodynamic Fluid Film Radial Bearing," U.S. Patent No. 5,427,455.

[22] Heshmat, H., Shapiro, W., and Gray, S. (1982), "Development of Foil Journal Bearings for High Load Capacity and High Speed Whirl Stability." Trans. of the ASME J. of Lubrication Technology, 104, 2, pp 149-156.

[23] Wagner, R.C. (1985), "Experimental Test Program for the Evaluation of Solid Lubricant Coatings as Applied to Compliant Foil Gas Bearings to 315 C," Masters Thesis, Case Western Reserve University, Cleveland, $\mathrm{OH}$.

[24] Inconel Alloy X-750, Huntington Alloy Products Division, The International Nickel Company, Huntington, WV 25720. Product Design Guide, (1970).

[25] DellaCorte, C. (1997), "A New Foil Air Bearing Test Rig for Use to $700{ }^{\circ} \mathrm{C}$ and $70,000 \mathrm{rpm}, "$ NASA TM-107405, prepared for the 1997 Tribology Conference cosponsored by STLE and the ASME, London, England, UK. See also Trib. Trans., 41, pp 335-340, July 1998.

[26] DellaCorte, C.; Zaldana, A.; Radil, K. (2004), "A Systems Approach to the Solid Lubrication of Foil Air Bearings for OilFree Turbomachinery", ASME J. of Trib., 126, pp 200-207. See also NASA/TM-2002-211482, ARL-TR-2867, October 2002

[27] Radil, K.C., Howard, S.A., and Dykas, B. (2002), "The Role of Radial Clearance on the Performance of Foil Air Bearings," NASA/TM-2002-211705

[28] Radil, K.C. and DellaCorte, C. (2002), "The Effect of Journal Roughness and Foil Coatings on the Performance of Heavily Loaded Foil Air Bearings," Trib. Trans., 45, 2, pp 199-204. See also NASA/TM-2001-210941, June 2001.

[29] Heshmat, H. (1999), "High Load Capacity Compliant Foil Hydrodynamic Journal Bearing," U.S. Patent No. 5,902,049.

[30] Kang, S.G. and Saville, M. (2005), "Hydrodynamic Journal Foil Bearing System," U.S. Patent No. 6,964,522.

[31] Weissert, D.H. (1999), "Compliant Foil Fluid Film Radial Bearing," U.S. Patent No. 5,915,841.

[32] Heshmat, H. (2000), "High Load Capacity Compliant Foil Hydrodynamic Journal Bearing,” U.S. Patent No. 6,158,893. 


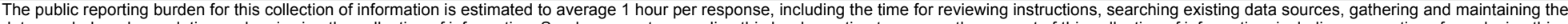

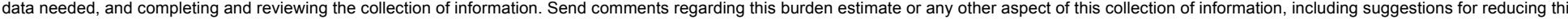

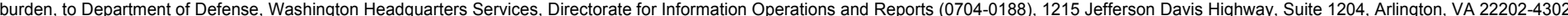

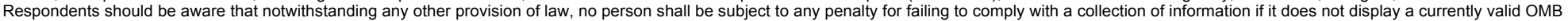
control number.

PLEASE DO NOT RETURN YOUR FORM TO THE ABOVE ADDRESS.

\section{REPORT DATE (DD-MM-YYYY) \\ 2. REPORT TYPE \\ 3. DATES COVERED (From - To)}

18-04-2007

Technical Memorandum

\section{TITLE AND SUBTITLE}

Design, Fabrication and Performance of Open Source Generation I and II

Compliant Hydrodynamic Gas Foil Bearings

5a. CONTRACT NUMBER

5b. GRANT NUMBER

5c. PROGRAM ELEMENT NUMBER

5d. PROJECT NUMBER

DellaCorte, Christopher; Radil, Kevin, C.; Bruckner, Robert, J.; Howard, S.,

Adam

5e. TASK NUMBER

5f. WORK UNIT NUMBER

WBS 877868.02.07.03.01.01

\section{PERFORMING ORGANIZATION NAME(S) AND ADDRESS(ES)}

National Aeronautics and Space Administration

John H. Glenn Research Center at Lewis Field

Cleveland, Ohio 44135-3191

\section{SPONSORING/MONITORING AGENCY NAME(S) AND ADDRESS(ES)}

National Aeronautics and Space Administration

Washington, DC 20546-0001

and

U.S. Army Research Laboratory

Adelphi, Maryland 20783-1145

\section{DISTRIBUTION/AVAILABILITY STATEMENT}

Unclassified-Unlimited

Subject Category: 23

Available electronically at http://gltrs.grc.nasa.gov

This publication is available from the NASA Center for AeroSpace Information, 301-621-0390

\section{SUPPLEMENTARY NOTES}

Portions of this report were presented at the 2007 International Joint Tribology Conference sponsored by STLE and ASME, San Diego, California, October 22-24, 2007. Christopher DellaCorte, Robert J. Bruckner, and S. Adam Howard, NASA Glenn Research Center,

Cleveland, Ohio 44135; and Kevin C. Radil, U.S. Army Research Laboratory, Glenn Research Center, Cleveland, Ohio 44135. Responsible person, Christopher DellaCorte, organization code RXT, 216-433-6056.

\section{ABSTRACT}

Foil gas bearings are self-acting hydrodynamic bearings made from sheet metal foils comprised of at least two layers. The innermost layer traps a gas pressure film that supports a load while a layer or layers underneath the top foil provide an elastic foundation. Foil bearings are used in many lightly loaded, high-speed turbo-machines such as compressors used for aircraft pressurization and small microturbines. Foil gas bearings allow the avoidance of an oil system that offers reduced weight and temperature capability. The general lack of familiarity of the foil bearing design and manufacturing process has hindered their widespread dissemination. This paper reviews the publicly available literature to demonstrate the design, fabrication and performance testing of both first and second generation bump style foil bearings. It is anticipated that this paper may serve as an effective starting point for new development activities with foil bearing technology.

\section{SUBJECT TERMS}

Bearings; Turbomachinery

\begin{tabular}{|l|l|l|c|c|}
\hline \multicolumn{2}{|l|}{ 16. SECURITY CLASSIFICATION OF: } & $\begin{array}{l}\text { 17. LIMITATION OF } \\
\text { ABSTRACT }\end{array}$ & $\begin{array}{l}\text { 18. NUMBER } \\
\text { OF }\end{array}$ \\
\begin{tabular}{|l|l|l|} 
a. REPORT \\
U
\end{tabular} & $\begin{array}{l}\text { b. ABSTRACT } \\
\text { PAGES } \\
\text { PAGE } \\
\text { U }\end{array}$ & & 21 \\
\end{tabular}

10. SPONSORING/MONITORS
ACRONYM(S)
NASA, ARL
11. SPONSORING/MONITORING
REPORT NUMBER
NASA/TM-2007-214691; ARL-TR-4102

REPORT NUMBER

E-15879 

